\title{
Service Quality Management in Hotel Industry: A Conceptual Framework for Food and Beverage Departments
}

\author{
Ala`a Nimer AbuKhalifeh ${ }^{1} \&$ Ahmad Puad Mat Som ${ }^{1}$ \\ ${ }^{1}$ School of Housing, Building and Planning, Universiti Sains Malaysia, Penang, Malaysia \\ Correspondence: Ala`a Nimer AbuKhalifeh, School of Housing, Building and Planning, Universiti Sains \\ Malaysia, Penang, Malaysia. Tel: 60-4-653-3741. E-mail: ana11_hbp046@student.usm.my
}

Received: March 8, 2012 Accepted: May 15, 2012 Online Published: July 16, 2012

doi:10.5539/ijbm.v7n14p135 URL: http://dx.doi.org/10.5539/ijbm.v7n14p135

\begin{abstract}
Service quality has been an important subject of research involving food and beverage (F\&B) departments of hotels. Despite a substantial number of studies on service quality, the reasons why guests revisit a hotel and why a high-quality service from the F\&B department is needed have remained unanswered. This paper aims to review existing literature on service quality management in the F\&B departments of hotels, its process, and the effective service quality management framework. This paper discusses famous models, and explains Parasuraman's dimensional framework of service quality management in the area of F\&B and its application to the hotel industry. The conceptual paper suggests application of the dimensional model in the F\&B department and encourages hotels to improve its management to better satisfy their guests.
\end{abstract}

Keywords: service quality, hotel industry, parasuraman dimensional model, food and beverage department

\section{Introduction}

Hotel management scholars consider service quality a precedent to guest satisfaction. Some experiential studies show that getting a good quality of service from the food and beverage (F\&B) department of a hotel is important for many guests (Armstrong et al., 1997; Crick \& Spencer, 2011; Cronin \& Taylor, 1992a; Getty \& Thompson, 1994; Lam \& Zhang, 1998; Parasuraman. et al., 1988a; Sulek \& Hensley, 2010; Zeithaml \& Bitner, 2003). Researchers have defined service quality in relation to the concept of consumer-perceived quality, which is based solely on the perspective of customers. Such a perception is built in a place where an organization supplies goods and services to customers in a manner that satisfies them and where they examine service quality (Babajide, 2011, p. 48; Carman, 1990; Choi \& Chu 1998; Christie 2002; Cronin et al., 2000; Gounaris et al., 2003; Mei et al., 1999; Mill, 2002; O’Neill, 2001; Oberoi \& Hales, 1990; Presbury et al., 2005; Qu \& Tsang, 1998; Rust \& Zahorik, 1993; Saleh \& Ryan, 1991; Zeithaml et al., 1996). In the hotel industry, service quality that satisfies customers is important to encourage them to revisit and to earn their loyalty (Carev, 2008; Carman, 1990; Jabulani, 2001; Parasuraman. et al., 1988a; Zeithaml \& Bitner, 2003) and satisfaction (Babajide, 2011, p. 48; Christie 2002; Hersh, 2010, p. 209; Ladhari, 2009, p. 311; Oliver, 1999).

Parasuraman et al. (1985; 1988b), Qu and Tsang (1998), and Zeithaml et al. (1996) define "perceived service quality" as the global evaluation by customers of the overall excellence or superiority of a service. The definition is similar to the concept of attitude. Based on the exploratory definition of service quality as perceived by customers, it is the gap (discrepancy) between a customer's expectation of a service and his perceptions of the actual service received (p. $254-255)$. Much of the recent research on service quality has been carried out within the framework of the SQ (service quality) model developed from the extensive research of Parasuraman et al. (1990, 1985, and 1988b), Qu \& Tsang (1998), and Zeithaml et al. (1996). Service quality has been discussed in various literatures, and one of the most largely used models measuring service quality is the SERVQUAL.

Taking on views from the study by Parasuraman et al. $(1995,1998)$, this study suggests that service quality and its dimensions are among the important factors influencing guest satisfaction. Considering the dimensions of service quality is, therefore, necessary as well. This dimension was focused on several studies on which hotel administrators received the support to implement the plan for improving service quality (AlRousan, 2011; Mohsin, 2011; Parasuraman et al., 1985). The benefits of a good service quality as far as the hotel industry is concerned include greater guest satisfaction and enhancement of employee performance (Cronin et al., 2000; Duncan \& Elliott, 2002; Johnson et al., 1995; Kang \& James, 2004; Lidén, 2003; Peter \& Nicole, 2006; Rust et al., 1995; 
Soutar et al., 2001; Su, 2004). Zeithaml and Bitner (2003) mentioned that perception of service quality becomes global depending on the prevalence of the service. The idea that service quality is a multidimensional concept is commonly accepted.

According to Antony and Ghosh (2004) and Harvey (1998), service quality covers meeting and exceeding customer expectations. This description has become popular since its inception in the late 1970s. The concept of service quality stemmed from the area of marketing, which puts importance to the relationship between a business and its customers. Service quality is intangible, making its measurement impossible. Evaluation of service quality largely depends on management of appearances and perceptions (p. 380).

This paper reviews existing literature and suggests a theoretical framework for F\&B department that illustrates the evaluation of service quality in the hotel industry in Jordan. It uses the five dimensions developed by Parasuraman et al. (1985) and Zeithaml et al. (1996). These five dimensions are the followings: (1) tangibles refer to physical facilities, equipment, appearance of personal, etc.; (2) reliability - ability to dependably and accurately perform the promised service; (3) responsiveness - willingness to help customers and provide prompt service; (4) assurance - knowledge and courtesy of employees, and their ability to convey trust and confidence; and (5) empathy - care for and individualized attention to guests.

\section{Theories and Models in Service Quality}

There are five dimensions of service quality, namely, tangibility (Cronin \& Taylor, 1992b; Kang \& James, 2004; Saleh \& Ryan, 1991; Zeithaml \& Bitner, 2003), reliability (AlRousan, 2011; Kotler \& Bloom, 1984; Ladhari, 2009, p. 311; Parasuraman. et al., 1988a), responsiveness (Antony \& Ghosh, 2004; Cheung \& Law, 1998; Knuston et al., 1991; Upal, 2008), assurance (Al Khattab, 2011; Cronin \& Taylor, 1992a; Pitt \& Jeantrout, 1994; Powapaka, 1996), and empathy (Harvey, 1998; Mohsin, 2011; Parasuraman. et al., 1988a; Qu \& Nelson, 1998; Zeithaml et al., 1993). Several studies have identified SERVQUAL, but Parasuraman et al. (1985) were the first to point out that the direction of marketing services is one of the considerations in guest administration. Service quality, such as in the hotel industry, is difficult to understand compared with product quality because the former is intangible. Several studies reported that the SERVQUAL scale is not universal because the dimensionality of service quality apparently depends on the type of service examined (Ladhari, 2009, p. 311).

There has been variable help for the validity of the SERVQUAL model in the hotel service industry (Ladhari, 2009, p. 311; Wilkins et al., 2007). Akan (1995) explores the applicability of the SERVQUAL model in the Turkish hospitality industry and identifies seven dimensions in the model: (1) courtesy and competence of the person, (2) communication and transactions, (3) tangibles, (4) knowledge and understanding of the customer, (5) accuracy and speed of service, study of the hotel industry, (6) solutions to problems; and (7) accuracy of hotel reservations. Mei et al. (1999) determine the dimensions of service quality in the Australian hotel industry and develop a new scale of service quality in the hospitality industry, called "HOLSERV," with three dimensions: (1) employees, (2) tangibles, and (3) reliability. Saleh and Ryan (1991) report five dimensions of service quality that differ from those in the SERVQUAL model: (1) conviviality; (2) tangibles; (3) reassurance; (4) avoidance of sarcasm; and (5) empathy. Oberoi and Hales (1990) suggest that service quality plays an important role in conference hotels in the United Kingdom and report that service-quality perception has two dimensions: (1) tangibles; and (2) intangibles.

Getty and Thompson (1994) describe the validity of the SERVQUAL dimensions in the hotel sector and report that only two of the dimensions (tangibles and reliability) are generic. Getty and Getty (2003) test the dimensions of service quality in the hotel industry in the United States and develop a new scale (called "lodging quality index") with five service-quality dimensions: (1) tangibility, (2) reliability, (3) responsiveness, (4) confidence, and (5) communication. Al Roussan (2011) examines Parasuraman model for hotel service quality and customer loyalty in Jordanian hotels using the Marriott hotel chain as a case study. The study discusses the five gaps in service quality in the context of Jordan and applies this model to the Marriott hotel chain to test its quality of service. The benefit of this framework is applying the elements of "various models" into a clarified hotel and tourism industry management as Parasuraman (1995, p. 1) says:

"Attainment of quality in products and services has become a pivotal concern in 1980 while the quality in tangible goods has been described and measured by marketers, quality of service is largely undefined and unresearched. The authors attempt to rectify this situation by reporting the insight obtained in an extensive exploration of quality in four service businesses and developing a model of service quality".

\section{Service Quality Dimensions}

The first definition, reliability is defined as the ability of a service supplier to promptly deliver a good quality of 
service. Observing service delivery contracts, pricing, and complaints handling are all important for a business. (AlRousan, 2011; Parasuraman et al., 1985; Tat \& Raymound, 1999). The second concept, responsiveness is the agreeableness to help guest by providing immediate service as soon as a request is received. The service guests will provide soon and prompt attention to all their guest requests, question and suggestion (Al Rousan, 2011; Knutson et al., 1990; Parasuraman et al., 1985). The third concept, assurance is with consideration to the service quality detention which considerates on the capability to activate trust and confidence of the product or service provided. The fourth dimension empathy is the service quality manner that stresses on the contacting of guest's as personalized. The end of this step, tangibility is the service dimension that makes a product or service practical and usable for customers (AlRousan, 2011; Parasuraman et al., 1985).

Figure 1 shows the Parasuraman dimensional SERVQUAL management framework.

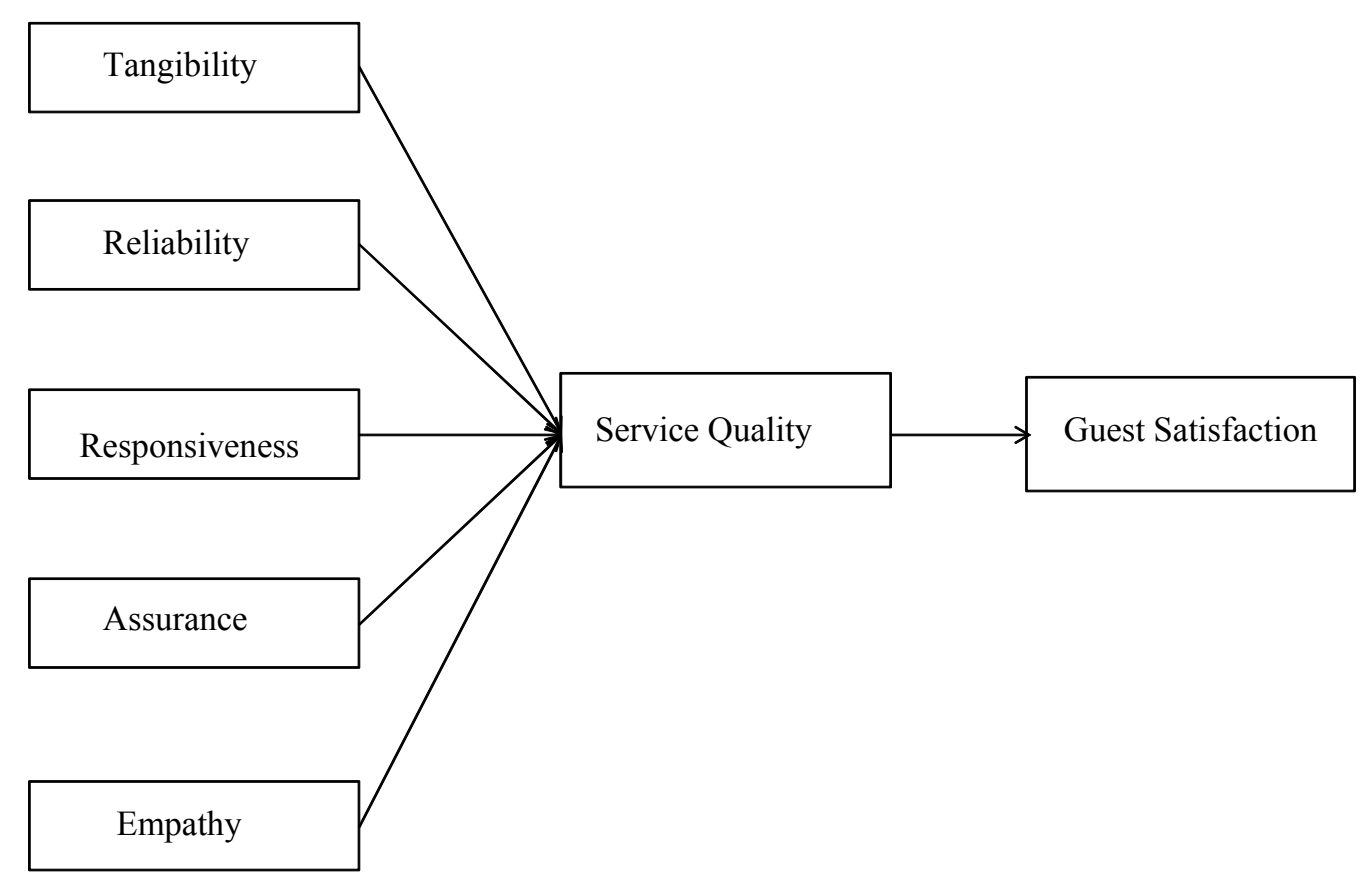

Figure 1. Parasuraman SERVQUAL management framework: adopted by Parasuraman et al. (1985)

\subsection{Guest Satisfaction}

Guest satisfaction is the evaluation of a guest whether or not the quality of a service meets his expectations. Performance that falls below expectations makes guests dissatisfied (Kottler \& Killer, 2006). In the hotel industry, satisfaction of guests is in terms of their satisfaction with the service of the F\&B department and the customer relations developed by hotel staff (Al Rousan, 2011; Parasuraman et al., 1985). Customer satisfaction is considered one of the most important outcomes of all marketing activities in a market-oriented firm. The obvious objective of satisfying a customer is to expand a business, to gain higher market share, and to acquire repeat and referral business, all of which lead to improved profitability (Barsky, 1992; Carev, 2008). However, the guest satisfaction concept in this model refers to judgement that depends on both good service quality and fitness of service to the needs of guests (Tse and Wilton, 1988). According to Parasuraman, guest satisfaction is the level in which expectation of a guest is met or exceeded. Carev (2008) defines service quality satisfaction based on overall consideration by a guest of the advantages of a service taking into account perceptions of what is reserved and what is given (Parasuraman. et al. 1988b). Service providers should be able to understand the behavior and needs of guests to be able to know how to satisfy them. Cheung and Law (1998) develop a new model for the measurement of hospitality SQ that incorporates performance of hotel employees in the SQ level. This new SQ for the customer satisfaction model, in turn, can be directly integrated into the hospitality TQ operation because SQ is a basic component of TQ. This new model prevails over the traditional SQ models in several areas. The new model is more comprehensive. Moreover, the new model better reflects the actual SQ situation that fits the TQ concept as both TQ and staff performance aim at sustained improvement. The former steers towards continual improvement of each process, whereas the latter is directed towards continual 
improvement in performance. (p. 402).

This study is one of the studies on the quality of the F\&B department in Jordanian hotels and its relationship with guest satisfaction and service quality. This study suggests a model that may be successfully applied to service quality. Furthermore, this study suggests the application of a guest satisfaction model that hotel managers may find useful. Finally there was an absence of competent data to design and develop hotel service quality and guest satisfaction. To benefit from this study, F\&B department and hotel management will develop and improve their service and guest satisfaction. Nevertheless, this study is expected to help F\&B departments and management of hotels to develop and improve their service and thus better satisfy their guests.

\section{Service Quality in Food and Beverage Departments}

F\&B department in the hotel industry has received considerable attention from researchers and academics given that this department may help guide the development of service quality in the entire F\&B industry (Arizon, 2010, p. 122). Understanding the antecedent of service quality" allows the hotel industry to concentrate on SERVQUAL models. Reviewing more than 32 empirical studies, Arizon (2010, p. 122) focuses on service quality delivery in the F\&B industry in the western Cape, evaluates factors that affect service quality, and explains SERVQUAL application and gaps in the hotel industry. Cho and Wong (1998 p. 285) show the relationship between service quality and guest satisfaction, and discuss the measurement of service quality using a computerized food and beverage cost control system. According to their study, "The gaps between management requirements and the functionality of computer systems could thereby be reduced. The average scores in terms of the expectations of all attributes are high, suggesting that there are few redundant functions/features in the existing FBCCSs in Hong Kong hotels." In another study, the Gui Hilton Helsinki Airport hotel is used as the main antecedent of breakfast service quality, which covers quality of food and reliability of service in restaurants. The gap between consumer expectation and management perception, as well as the gap between service quality specification and service delivery leads to a gap in perceived service quality (Babajide, 2011, p. 48). Ruetzler (2008) has three studies on food and beverage, namely, "Service Quality and Culture," "Service Quality and School Food Service," and "Service Quality Model."

Nield et al. (2000) affirm "the role and importance of food service in tourist satisfaction and the differences in satisfaction levels among regional groups. Analysis of the findings reveals that significant differences existed between satisfaction perception of three tourist groups on value for money, quality of food, a number of dishes, food service standards, variety of dishes, and presentation of food and speed of service in general, bread, coffee, meat, and soup in particular. Overall results further indicate that quality of food, value for money, variety of dishes, attractiveness of the surroundings, and presentation of food were the attributes that most affected the overall food service experience in Romania (p. 375). Result of their study show that food service is an important contributor to tourist satisfaction, and that there are significant differences in satisfaction levels with food service between eastern and western European, and Romanian tourists. They confirm that guest satisfaction plays a very important role in the hotel and tourism industry.

In the study by Sriyam (2010, pp. 7-17), the use of the SERVQUAL approach to measure service quality in hotel and other service industries is accepted. The study explores expectation and perception levels of customers towards service quality that focuses on the front office staff and service quality dimensions in other hotel departments, such as that of F\&B. Moreover, the SERVQUAL model scale enables actual measurement of service quality. The model on which SERVQUAL is based allows customers to evaluate quality of a service based on five distinct dimensions: tangibles, reliability, responsiveness, assurance, and empathy. The provision of individualized attention to customers and the use of this model are suggested by previous studies (e.g., Lin, 2006; and Nield et al., 2000). In existing literatures, theories and models for measuring service quality in food and beverage departments are recommended and recognized as indicators of SERVQUAL (Al Khattab, 2011a; Al Rousan, 2011; Christie 2002; Gazzoli et al., 2009; Getty \& Getty, 2003; Gronroos, 1990; Knutson et al., 1990; Mill, 2002; Oliver, 1980; Qu \& Nelson, 1998; Richards \& Allaway 1993).

\section{Conclusions}

It can generally be contested that there are two perspectives to explain Parasuraman's model. Firstly, the guests directly gain loyalty from the service quality dimensions: 'tangibles, reliability, responsiveness, assurance, and empathy'. When they perceive a higher service quality, they will ultimately turn into a loyal guest of a specific service quality provided such as the F\&B department, and secondly, guests may have higher satisfaction level. The application of this model by hotels can bring success for food and beverage departments to achieve high service quality which has a direct effect on satisfaction level of guests. As this paper is only conceptual, future studies may incorporate empirical data that will be collected from F\&B departments in selected hotels in Jordan. 


\section{Acknowledgement}

This research has partially been supported by Universiti Sains Malaysia's fellowship scheme and research grant (1001/PTS/8660013).

\section{References}

Al Khattab, S. S. J. (2011). Perceptions of Service Quality in Jordanian Hotels. International Journal of Business and Management, 6(7). http://dx.doi.org/10.5539/ijbm.v6n7p226

Al Rousan, R. M. R. (2011). Hotel service quality and customer loyalety in Jordanian hotels: A case stady of marriott hotels chain. University Saiance Malaysia Pula Pinang.

Antony, J. F., \& Ghosh, S. (2004). Evaluating service quality in a UK hotel chain: a case study. International Journal of Contemporary Hospitality Management, $\quad$ 16(6), http://dx.doi.org/10.1108/09596110410550833

Armstrong, R. W., Mok, C., Go, F. M., \& Chan, A. (1997). The importance of cross-cultural expectations in the measurement of service quality perceptions in the hotel industry. International Journal of Hospitality Management, 16(2), 181-190. http://dx.doi.org/10.1016/S0278-4319(97)00004-2

Babajide, O. (2011). Breakfast service quality in Restaurant Gui Hilton Helsinki Airport hotel. Bachelor's Thesis, HAAGA- HELIA University of applied sciences. Retrieved from https://publications.theseus.fi/bitstream/handle/10024

Carev, D. (2008). Guest satesfaction and gest loyalety study for hotel industry. College of Applied Science and Technology, Pro Quest. database.

Carman, J. M. (1990). Consumer perceptions of service quality: an assessment of the SERVQUAL dimensions. Journal of Retailing, 66(1), 33-55.

Cheung, C., \& Law, R. (1998). Hospitality service quality and the role of performance appraisal. Journal of managing service quality, 8(6), 402-406.

Choi , T. Y., \& Chu , R. K. S. (1998). Consumer perceptions of the quality of services in three hotel categories in Hong Kong. Journal of Vacation Marketing, 5(2), 176-189.

Christie, R. M. (2002). A Comprehensive Model of Customer Satisfaction in Hospitality and Tourism: Strategic Implications for Management. International Business \&Economics Research Journal, 1(6), 8-18.

Crick, A. P., \& Spencer, A. (2011). Hospitality quality: new directions and new challenges. International Journal of Contemporary Hospitality Management, $\quad$ 23(4), http://dx.doi.org/10.1108/09596111111129986

Cronin, J. J., \& Taylor, S. A. (1992a). SERVPERF versus SURVQUAL:reconciling performance - based and perceptions - minus - expectations measurment of service quality. The Journal of Marketing, 58, 55-68. http://dx.doi.org/10.2307/1252296

Cronin, J. J., Brady, M. K., \& Hult, G. T. (2000). Assessing effects of the quality, value, and customer satesfaction on consumeral behavioral intentions in service environments. Journal of Retailing, 76(2), 193218. http://dx.doi.org/10.1016/S0022-4359(00)00028-2

Duncan, E., \& Elliott, G. (2002). Customer service quality and financial performance among Australian retail financial institutions. Journal of Financial Services Marketing, 7(1), 25-41.

Getty , J. M., \& Thompson, N. K. (1994). The relationship between quality, satisfaction, and recommending behaviour in lodging decisions. Journal of Hospitality and Leisure Marketing, 2, 3-22. http://dx.doi.org/10.1300/J150v02n03_02

Gounaris, S. P., Stathakopoulos, V., \& Athanassopoulos, A. D. (2003). Antecedents to perceived service quality: an exploratory study in the banking industry. The International Journal of Bank Marketing, 21(4/5), 168190. http://dx.doi.org/10.1108/02652320310479178

Harvey, J. (1998). Service quality: a tutorial. Journal of Operations Management, 16, 583-597. http://dx.doi.org/10.1016/S0272-6963(97)00026-0

Hersh, A. M. (2010). Evaluate the impact of Tourism Services Quality on customer's satisfaction. Interdisciplinary journal of contemporary research in business, 2(6), 1-29. 
Jabulani, N. (2001). An examination of customer service employees self effeicancy, job stesfaction, demographic factors, and customer perception of hotel service quality delevery in jamaica. Noava southeastrean universitey USA, ProQuest Information database.

Johnson, R. L., Tsirps, M., \& Lancioni, R. A. (1995). Measuring service quality: A systems approach. Journal of Services Marketing, 5, 6-19. http://dx.doi.org/10.1108/08876049510100272

Kang, G. D., \& James, J. J. (2004). Service quality dimensions: an examination of Gro"nroos's service quality $\begin{array}{lllll}\text { model. Journal of Managing } & \text { Service }\end{array}$ http://dx.doi.org/10.1108/09604520410546806

Knuston, B., Stevens, P., Wullaert, C., Patton, M., \& Yokoyama, F. (1991). Lodgserv: A service quality index for the lodging industry. Hospitality Research Journal, 14(3), 277-284.

Knutson, B., Stevens, P., Wullaert, C., Patton, M., \& Yokoyama, F. (1990). LODGSERV: a service quality index for the lodging industry. Hospitality Research Journal, 14(2), 227-284.

Kotler, P., \& Bloom, P. N. (1984). Marketing professtional services. Engleewood cliffs, NJ: Prentice - Hall.

Ladhari, R. (2009). Service quality, emotional satisfaction, and behavioural intentions A study in the hotel industry. Journal of Managing Service Quality .Emerald Group Publishing Limited, 19(3), 309-331. http://dx.doi.org/10.1108/09604520910955320

Lam, T., \& Zhang, Q. A. (1998). Study of service quality: the case of travel agents in Hong Kong. Tourism and Hotel Industry in Indo-China South East Asia. Paper presented at the Development Marketing and Sustainability, 3rd International Conference, Proceedings 4-6 June, Thailand.

Lidén, S. B. (2003). Customer expectations on service guarantees. Managing Service Quality, 13(5), 338-348. http://dx.doi.org/10.1108/09604520310495822

Mei, A. W. O., Dean, A. M., \& White, C. J. (1999). Analyzing service quality in the hospitality industry. Journal of Managing Service Quality, 9(2), 136-143. http://dx.doi.org/10.1108/09604529910257920

Mill, R. C. (2002). A Comprehensive Model Of Customer Satisfaction In Hospitality And Tourism:Strategic Implications For Management. International Business \& Economics Research Journal, 1(6), 7-18.

Mohsin, A. (2011). Exploring Service Quality in Luxury Hotels: Case of Lahore, Pakistan. The Journal of American Academy of Business, Cambridge, 16(2), 296-303.

O’Neill, M. A. (2001). Measuring service quality and customer satisfaction. In J. Kandampully., C. Mok, \& B. Sparks, (Eds.), Service quality management in hospitality, tourism and leisure. New York: Haworth Hospitality Press.

Oberoi, U., \& Hales, C. (1990). Assessing the quality of the conference hotel service product:towards an empirically based model. Service Industries Journal, 10(4), 21-700. http://dx.doi.org/10.1080/02642069000000083

Oliver. (1999). Whence Consumer Loyalty? International Journal of Marketing, 63, 33-44.

Parasuraman, A., Zeithaml, V. A., \& Berry, L. L. (1985). A conceptual model of service quality and its implications for future research. Journal of Marketing, 49, 41-50. http://dx.doi.org/10.2307/1251430

Parasuraman., Zeithaml, V. A., \& Berry, L. L. (1988a). SERVQUAL: a multiple item scale for measuring consumer perceptions of service quality. Journal of Retailing, 64(1), 12-40.

Peter, S. C., \& Nicole, K. (2006). Swedish hotel service quality and loyality dimention. Advances in Hospitality and Leisure, 2, 123-157. http://dx.doi.org/10.1016/S1745-3542(05)02007-2

Pitt, L. F., \& Jeantrout, B. (1994). Management of customer expectations in service firms: A study and a checklist. The Service Industries Journal, 14(2), 170-189. http://dx.doi.org/10.1080/02642069400000021

Powapaka, S. (1996). The role of outcom quality as adeterminantof overall service quality in different categories of service industries: an empirical investigation. Journal of Services Marketing, 10(2), 5-25 http://dx.doi.org/10.1108/08876049610114230

Presbury, R., Fitzgerald, A., \& Chapman, R. (2005). Impediments to improvements in service quality in luxury hotels. Managing Service Quality, 15(4), 357-373. http://dx.doi.org/10.1108/09604520510606835

Qu, H., \& Nelson, T. (1998). Service Quality Gap in China's Hotel Industry: a Study of Tourist Perceptions and Expectations. Journal of Hospitality \& Tourism Research, 22(3), 252-267. 
http://dx.doi.org/10.1177/109634809802200304

Rust, R. T., \& Zahorik, A. J. (1993). Customer satesfaction, customer retention, and market share. Journal of Retailing, 69(2), 103-125. http://dx.doi.org/10.1016/0022-4359(93)90003-2

Rust, R. T., Zahorik, A. J., \& Keiningham, T. L. (1995). Return on quality (ROQ): Making service quality financally accountable. The Journal of Marketing, 59(2), 58-70. http://dx.doi.org/10.2307/1252073

Saleh, F., \& Ryan, C. (1991). Analysing service quality in the hospitality industry using the SERVQUAL model. Services Industries Journal, 11(3), 324-343. http://dx.doi.org/10.1080/02642069100000049

Soutar, G. N., Mok, C., \& Sparks, B. (2001). Service quality, customer satisfaction, and value: an examination of their relation-ships in Kandampully Service quality management in hospitality, tour-ism, and leisure. New York: The Haworth Hospitality Press.

$\mathrm{Su}, \mathrm{A}$. Y. L. (2004). Customer satisfaction measurement practice in Taiwan hotels. Journal of Hospitality Management, 23, 397-408. http://dx.doi.org/10.1016/j.ijhm.2004.02.002

Sulek, J. S., \& Hensley, R. L. (2010). Updating service operations. Managing Service Quality, 20(5), 475-489. http://dx.doi.org/10.1108/09604521011073759

Tat, Y. C., \& Raymound, K. S. C. (1999). Consumer perceptions of the quality of services in three hotel categories in Hong Kong. Journal of Vacation Marketing, 5(2), 176-189. http://dx.doi.org/10.1177/135676679900500206

Upal, M. (2008). Telecommunication Service Gap: Call Center Service Quality Perception and Satisfaction. Journal of Communications of the IBIMA, 3.

Zeithaml, Berry, L. L., \& Parasuraman, A. (1993). The Nature and Determints of customer expectations of service. Journal of the academy of Marketing service, 21(1), 1.

Zeithaml, Berry, L., \& Parasuraman, A. (1996). The behavioural consequenses of service quality. Journal of Marketing, 60, 31-46. http://dx.doi.org/10.2307/1251929

Zeithaml., \& Bitner, M. J. (2003). Services Marketing: Integrating Customer Focus Across the Firm. New York: McGraw-Hill. 